\title{
Halina Wiśniewska \\ Polszczyzna przez wieki \\ Wydawnictwo Wyższej Szkoły Humanistyczno-Ekonomicznej w Lodzi \\ Lódź 2009, ss. 390
}

Obszerna książka Profesor Haliny Wiśniewskiej ma charakter podręcznikowy i jest syntezą dziejów języka polskiego od czasów średniowiecza do epoki oświecenia. Autorka adresuje swój podręcznik do uczniów i studentów - humanistów różnych szkół wyższych i średnich, zaznaczając, że podaje $\mathrm{w}$ sposób stosunkowo zwięzły i poparty najnowszymi badaniami $\mathrm{z}$ historii polszczyzny podstawowe wiadomości, dotyczące tekstów pisanych/mówionych naszego języka z uwzględnieniem kontekstów kulturowych, które spowodowały zmiany w porozumiewaniu się $\mathrm{w}$ ojczystym języku $\mathrm{w}$ ciągu wieków, gdy łacina była językiem panującym w sytuacjach oficjalnych i uroczystych Rzeczpospolitej szlacheckiej.

Tak zarysowany temat i cel opracowania historycznojęzykowego został zrealizowany $\mathrm{w}$ oparciu o ściśle sformułowane założenia metodologiczne.

Przede wszystkim H. Wiśniewska uznała, mając na uwadze nowe koncepcje teoretyczne lingwistów, że historię polszczyzny należy wpisać w rozległy kontekst pozajęzykowy. „Na skutek tego mniej uwagi zwraca się na opisy systemu gramatycznego języka, więcej - na ówczesną leksykę i teksty, które informują nas o zachowaniach językowych Polaków, gdy nasz język ojczysty uznawano za gorszy, gdyż służył codzienności i tym, którzy nie mieli wykształcenia. Przez przywołanie autentycznych zapisów, ich opisy, analizy i interpretację rozmaitych zjawisk naszej kultury, wypowiadania się w ciągu wieków, chciałabym uświadomić, jak powiększała się nie tylko grupa nadawców tekstów, ale także rozszerzała 
się społeczność zainteresowana pisaniem i czytaniem po polsku" (s. 7-8). Przy czym Autorka opracowania przyjęła założenie, że historyczny status języka polskiego należy określać w ciągłej konfrontacji z rangą i rolą języka łacińskiego aż do doby nowopolskiej.

$\mathrm{Z}$ takim założeniem koresponduje wyznaczenie granic chronologicznych dla opisywanych dziejów języka polskiego, bowiem dzieje te otwiera epoka wczesnośredniowieczna, kiedy to doszło do najdawniejszych kontaktów języka polskiego z językiem łacińskim, a zamyka epoka oświeceniowa, kiedy to „w szkołach i na Uniwersytecie Krakowskim język ojczysty - polski stał się językiem pierwszym" (s. 8). Między tak wyznaczonymi cezurami język polski nie był uprawniony, zdaniem $\mathrm{H}$. Wiśniewskiej, do spełniania wszystkich funkcji w państwie, a funkcję języka naukowego, religijnego, publicystycznego i urzędowego spełniała wówczas łacina.

Wewnętrzne uporządkowanie chronologiczne dziejów polszczyzny oparła Autorka na periodyzacji epok literackich, uzasadniając to pragmatyką dydaktyczną, czyli dążeniem do ułatwienia odbiorcom publikacji zapamiętywania faktów i zjawisk historycznojęzykowych.

Już we wstępie do Polszczyzny... H. Wiśniewska deklaruje selektywne podejście do ogromnego przedsięwzięcia badawczego, które sprowadza się do wyboru tylko kilku zagadnień dla każdej epoki. Kolejny zabieg selektywny polega na tym, że badaczka wyłącza $\mathrm{z}$ analiz dorobek wybitnych poetów i pisarzy, koncentrując swoją uwagę przede wszystkim na piśmiennictwie autorów podręczników do nauki języka polskiego (rozmówki, gramatyki, stylistyki, słowniki), twórców lub tłumaczy literatury rozrywkowej (romanse, historyje) i autorów tekstów użytkowych (itineraria, listy, pamiętniki, panegiryki, rękopisy silva rerum, kalendarze, polemiki religijne, protokoły pisarzy miejskich i cechowych, prowadzących księgi sądownicze i rzemieślnicze). Taki dobór materiałów źródłowych wskazuje wprost, że H. Wiśniewska rekonstruowała historię polszczyzny używanej w powszechnym, a nie tylko elitarnym, kręgu komunikacyjnym, której dzieje nie były dotąd przedmiotem syntezy historycznojęzykowej. Obfitość przytaczanych w książce źródeł czyni z niej zarazem swoistą antologię tekstów polskich z różnych epok rozwojowych polszczyzny.

Na centralną część recenzowanego opracowania składa się pięć rozdziałów: 1. Czasy średniowiecza, 2. Czasy renesansu, 3. Czasy baroku, 4. Czasy saskie, 5. Czasy oświecenia; wyodrębnionych zgodnie z przyjętą 
periodyzacją historycznoliteracką, które mają powtarzalną wewnętrzną kompozycję, co porządkuje całościowo tok omawianych zagadnień. W kolejności zagadnienia te przedstawiane są następująco: a) sytuacja komunikacyjna, b) konteksty pozajęzykowe, c) komunikacja w języku ojczystym, d) słowniki języka polskiego, e) ciekawostki lingwistyczne i obyczajowe. W charakterystyce sytuacji komunikacyjnej określonej epoki uwzględniane są aspekty socjolingwistyczne, pragmatyczne i genologiczne. Konteksty pozajęzykowe obejmują kwestie polityczne, gospodarcze i kulturowe. Komunikacja w języku ojczystym to wykład zasadniczy w danym rozdziale opracowania, który obejmuje pięć-siedem problemów, ze szczególnym uwzględnieniem nowej tematyki tekstów pisanych (użytkowych, naukowych, czasem artystycznych), ich kompozycji, leksyki, frazeologii i onomastyki. Każdy rozdział zamyka zestawienie leksykonów i różnego typu wypowiedzi z danej epoki.

Dzieje polszczyzny w czasach średniowiecznych (s. 12-58) obejmują w podręczniku H. Wiśniewskiej okres od połowy wieku XII do końca wieku XV, jednakże w tym rozdziale znajdują się też wzmianki o sytuacji języka polskiego $\mathrm{w}$ wiekach wcześniejszych i porównawcze odniesienia do epoki renesansowej. Z charakterystyki sytuacji komunikacyjnej wynika, że w średniowieczu nadawcami tekstów pisanych w języku polskim i mówionych o charakterze publicznym byli przede wszystkim reprezentanci środowisk kościelnych i akademickich, adresujący swe wypowiedzi do wąskiej elity piśmiennej i odbiorców niepiśmiennych. W dalszych partiach tego rozdziału, pisząc o otoczeniu zewnątrzjęzykowym, w jakim przyszło funkcjonować językowi polskiemu, Autorka zwraca uwagę na wielowiekowe kontakty językowe w epoce średniowiecza polszczyzny i łaciny, które wyznaczały różne rangi tym językom; językiem urzędowym i literackim była łacina, a język polski był używany przede wszystkim w sytuacjach nieoficjalnych, rozszerzając stopniowo swój zakres użycia w komunikacji kościelnej (kazania, modlitwy) i urzędowej (sądownictwo). Pozytywnym następstwem tych kontaktów językowych było, jak pisze $\mathrm{H}$. Wiśniewska, kształcenie sprawności wypowiadania się $\mathrm{w}$ języku polskim przez naśladowanie poznanych doskonałych wzorów poetów, pisarzy i uczonych latynistów z czasów starożytnych lub średniowiecznych.

Podrozdział o średniowiecznej komunikacji w języku ojczystym wypełnia analiza najdawniejszego nazewnictwa, przede wszystkim osobowego, grafii polskiej w jej początkowej fazie rozwojowej i sporej grupy 
różnogatunkowych tekstów pisanych. Z analizy tej wypływają istotne uogólnienia. Przede wszystkim Autorka podała tu nieznane dotąd onimy z późnośredniowiecznych ksiąg miejskich Przemyśla, które dokumentują dynamikę rozwojową polskiej antroponimii oficjalnej i potocznej oraz, przywołując znane już historykom języka teksty, zwłaszcza z wieku XV, wskazała na różnogatunkowość tego niezbyt liczebnego piśmiennictwa i jego obieg w różnych kręgach społecznych.

Charakteryzując sytuację komunikacyjną w epoce renesansowej (s. 59-137), H. Wiśniewska podkreśla, że teksty pisane powstawały wówczas głównie w kręgu uczonych świeckich i duchownych oraz pisarzy i poetów, a ich odbiorcami byli zwłaszcza wykształceni w kraju i za granicą przedstawiciele środowisk szlacheckich i mieszczańskich, a także religijnych. Radykalnemu upowszechnieniu słowa pisanego w XVI wieku sprzyjał druk książek i rozeznanie w potrzebach rynkowych ówczesnych przedsiębiorczych drukarzy

Ze względu na liczne tłumaczenia tekstów obcojęzycznych z różnych zakresów tematycznych, wzbogacających rynek czytelniczy i włączających Polaków w zachodni krąg kulturowy, Autorka Polszczyzny... uważa, że „dzięki temu wiek XVI można nazwać wiekiem translacji literatury obcej na język polski" (s. 71). Z tego okresu zachowały się również przekłady tekstów polskich na łacinę i inne języki (np. Marcina Kromera, Bartłomieja Paprockiego, Hieronima Powodowskiego). Wówczas to „polszczyzna przeżywała pierwszy okres częściowej nobilitacji i stawała się w wąskim zakresie językiem tekstów »uczonych ", co przyczyniało się także do integracji narodowościowej" (s. 76). Rangę tę wzmacniały gramatyki, leksykony i liczne wypowiedzi o roli i statusie języka polskiego. Zdaniem $\mathrm{H}$. Wiśniewskiej polszczyzna sporo zawdzięcza umysłowemu ruchowi religijnemu w XVI wieku, kiedy to wiele mówiono i pisano w ojczystym języku, dzięki czemu pomnażał się zasób leksykalny języka polskiego oraz jego składnia i frazeologia.

Innowacją $\mathrm{w}$ recenzowanym podręczniku historycznojęzykowym jest wskazanie nowych dość obszernych sfer użycia języka polskiego w XVI-wiecznym miejskim piśmiennictwie kancelaryjnym, w którym znajdują się ogromne zasoby, przytaczanej w opracowaniu tylko przykładowo, leksyki profesjonalnej.

Mimo ciągłego, łacińsko-polskiego bilingwizmu polszczyzna w XVI wieku była już $\mathrm{w}$ stanie utrwalić i w miarę subtelnie kontrastować oraz wartościować, zdaniem Autorki, renesansowe opozycyjne portrety oso- 
bowe (człowiek poczciwy - człowiek niepoczciwy) w tekstach artystycznych, co jest językowym odzwierciedleniem ówczesnego postrzegania świata.

Dzieje polszczyzny XVII wieku (s. 141-239) H. Wiśniewska przedstawiła na tle ówczesnych uwarunkowań społeczno-kulturowych, zwracając uwagę na rolę zakonu jezuitów, który prowadził latynizację szkolnictwa, ale $\mathrm{z}$ drugiej strony na programy kształcenia w szkołach Nowodworskich, które zalecały z kolei równomierne posługiwanie się językiem polskim i łacińskim. W tym rozdziale opracowania $\mathrm{H}$. Wiśniewska udokumentowała obfitym materiałem, że mimo niesprzyjających warunków politycznych i kulturowych, polszczyzna ewoluowała i nabierała nowych znamion stylistycznych w rozmaitych sferach użycia. Rozwarstwienie semantyczne i morfologiczne leksyki zdeterminowane socjolingwistycznie zostało ukazane na podstawie słownictwa z zakresu sztuki kulinarnej, leksyka i frazeologia wojskowa tkwiąca w wielu tekstach siedemnastowiecznych poddana została z kolei kategoryzacji etymologicznej, analiza leksyki miłosnej z utworów Jana Andrzeja Morsztyna potwierdziła tezę o ciągłości występowania określonych kategorii semantycznych w tego typu słownictwie, a dowcip słowny $\mathrm{w}$ różnogatunkowych tekstach artystycznych był opisywany od strony fonetycznej, słowotwórczej i semantycznej.

W tej części opracowania znajdują się jeszcze dwa istotne podrozdziały, z których jeden przynosi spory zbiór, jak na publikację podręcznikową, leksyki specjalistycznej zawartej w ówczesnych gramatykach i profesjonalizmów leksykalnych $\mathrm{z}$ różnych dyscyplin zawodowych. Kolejny dokumentuje funkcjonowanie i popularność w XVII wieku licznych pism spoza obiegu artystycznego, takich jak np. pamiętniki, panegiryki, listy, kalendarze czy księgi domowe zwane też silva rerum. Przywołanie tych zapisów, składających się przecież na udokumentowane filologicznie dzieje języka polskiego, wprowadza w obieg czytelniczy nieupowszechnione dotąd zabytki piśmiennictwa narodowego.

Dzieje języka polskiego w czasach saskich (s. 241-308), czyli od przełomu wieków XVII i XVIII do 1763 roku, przedstawia H. Wiśniewska, przywołując zróżnicowane tematycznie i gatunkowo piśmiennictwo tej epoki. Znamienne dla tego czasu były - zdaniem Autorki - mowy (oracje) o charakterze okolicznościowym realizujące określony schemat kompozycyjny. Oracje te, jak i inne sformalizowane gatunki ówczesnych wypowiedzi publicznych i prywatnych, znalazły swoją kodyfikację w znanym dziele Wojciecha Bystrzonowskiego. Mając na uwadze liczne wyda- 
nia mów, traktatów, rozpraw, tekstów religijnych i dewocyjnych, Autorka opracowania stwierdza, że sądy o regresie tekstów do czytania w epoce saskiej nie mają potwierdzenia ilościowego. Następny nurt piśmiennictwa z czasów saskich to różnotematyczne teksty niewiast $\mathrm{z}$ tej epoki, tj. Elżbiety Drużbackiej, Franciszki Urszuli Radziwiłłowej, Katarzyny Zamoyskiej, Reginy Pilsztynowej czy Barbary Sanguszkowej. Teksty te, wolne od makaronizowania, konceptów, egzemplów i dalekich skojarzeniowo metafor, dokumentują polszczyznę standardową epoki saskiej, która była podstawą porozumiewania się całego ówczesnego społeczeństwa. W tym rozdziale podręcznika zostały przedstawione jeszcze inne zagadnienia, tj. funkcjonowanie pojęć czarownica, czary, Sarmata i sarmacki w różnego typu tekstach i leksykonach oraz struktura kalendarzy, jako popularnych podręczników wiedzy z różnych zakresów. Swoistą wartość ma także encyklopedia Chmielowskiego, która - zdaniem Autorki - prezentuje ówczesny styl popularnonaukowy. Obfitość przytaczanych źródeł z epoki saskiej, ukazanie ich funkcjonowania w tym czasie, a także analizy tychże materiałów historycznojęzykowych rekonstruują różne nurty rozwojowe języka polskiego w pierwszej połowie XVIII wieku.

Dzieje języka polskiego w epoce oświecenia (czasy stanisławowskie i późnooświeceniowe) (s. 308-372) rozpatruje H. Wiśniewska w kontekście wielkich reform, które zmieniły mentalność Polaków, co przejawiło się także w przekonaniu, że język polski jest tworzywem spajającym państwo i naród. Świadczą o tym wypowiedzi ludzi oświecenia, np. Ignacego Włodka, Hugona Kołłątaja czy Adama Kazimierza Czartoryskiego, a także powołanie takich instytucji jak Komisja Edukacji Narodowej i Towarzystwo do Ksiąg Elementarnych. Zdaniem Autorki opracowania, światli ludzie epoki oświeceniowej stosowali nowoczesne sposoby perswazyjne, by zmienić poglądy o języku ojczystym i nieznanej ogółowi łacinie. Przejawem dążenia do owych zmian były publikacje podręczników szkolnych napisanych w języku polskim, takich autorów, jak Walenty Szylarski (gramatyka), Onufry Kopczyński (gramatyka), Adam Naruszewicz (historia) czy Andrzej Gawroński (geometria), i leksykonów, a przede wszystkim słownika Samuela Bogumiła Lindego. W tym nurcie znajduje się także Sztuka rymotwórcza Franciszka Ksawerego Dmochowskiego z wypowiedziami o języku ojczystym.

W kolejnych podrozdziałach $\mathrm{H}$. Wiśniewska analizuje wybrane, ale najważniejsze, pojęcia $\mathrm{z}$ epoki oświeceniowej, takie jak nauka i wolność na podstawie Powinności nauczyciela... Grzegorza Piramowicza i Konstytucji 
3 Maja, widząc w nich nośne treści perswazyjne. W polszczyźnie epoki oświecenia istotne miejsce zajmują, zdaniem Autorki, nowe terminy techniczne, które pojawiły się w publikowanej wówczas literaturze profesjonalnej, oraz językowe eksponenty potoczne i emocjonalne, zawarte w tekstach Ignacego Krasickiego i Józefa Wybickiego, które wskazują z kolei na innowacyjność stylową wspomnianych pisarzy.

Książkę H. Wiśniewskiej zamyka krótkie podsumowanie, zestaw wybranych pozycji bibliograficznych, indeks nazwisk i spis ilustracji.

Recenzowana synteza historycznojęzykowa jest istotnie nowym opracowaniem dziejów języka polskiego z wyraźnym nastawieniem dydaktycznym, które zapewne wynika też z akademickiego doświadczenia Autorki dzieła. H. Wiśniewska w swoim podręczniku zrealizowała założenie integralnego traktowania dziejów języka polskiego w wersji na ogół nieartystycznej z jego historią zewnętrzną, by pokazać, że język jest trwałym składnikiem tożsamości narodowej. Ten interdyscyplinarny charakter opracowania zapewne sprawi, że jego czytelnikami będą nie tylko lingwiści, ale również ci wszyscy, którzy będą poznawać i badać przeszłość polskiej wspólnoty etnicznej.

\author{
Józef Kość \\ Uniwersytet Marii Curie-Skłodowskiej \\ w Lublinie
}

